\title{
The existential self: challenging and renegotiating gender identity through higher education in England
}

Article

Accepted Version

Fuller, C. (2018) The existential self: challenging and renegotiating gender identity through higher education in England. Gender and Education, 30 (1). pp. 92-104. ISSN 1360-0516 doi:

https://doi.org/10.1080/09540253.2016.1241380 Available at https://centaur.reading.ac.uk/66631/

It is advisable to refer to the publisher's version if you intend to cite from the work. See Guidance on citing.

To link to this article DOI: http://dx.doi.org/10.1080/09540253.2016.1241380

Publisher: Taylor and Francis

All outputs in CentAUR are protected by Intellectual Property Rights law, including copyright law. Copyright and IPR is retained by the creators or other copyright holders. Terms and conditions for use of this material are defined in the End User Agreement.

www.reading.ac.uk/centaur 
Central Archive at the University of Reading

Reading's research outputs online 


\title{
The Existential Self: Challenging and Renegotiating Gender Identity through Higher Education in England (7,060)
}

Dr Carol Fuller* Institute of Education, University of Reading, 4 Redlands Road, Reading, Berkshire, UK, RG1 5EX c.l.fuller@ reading.ac.uk Tel: 01183782662

*Corresponding author, Institute of Education, University of Reading, 4 Redlands Road, Reading, Berkshire,UK, RG1 5EX c.l.fuller@reading.ac.uk

This research was carried out at the University of Reading

\begin{abstract}
This article explores perceptions of the role of education as a potential medium of transformation and a vehicle to challenge and renegotiate symbolic and cultural notions of gender identity. Drawing on data collected at two time points over ten years, it considers four young women from working class backgrounds in England who aspired to and then went on to higher education. It considers their earlier aspiration, their current occupations and how these link to their sense of a gendered self. In doing so it raises important questions about persisting cultural hegemony that promotes equality yet continues to position women as 'mother' and 'homemaker', leaving those who reject the identity feeling defiant and defensive. It also considers how, on the one, hand higher education can provide the means to renegotiate and redefine who one wants to be, yet on the other, does so at what appears to be the cost of existential angst.
\end{abstract}

Keywords: Identity; Female: Education; Existential

\section{Introduction}

Feminist research has focused on the ways that education functions to create, shape and reproduce gendered inequalities. As well as considering the structural and ideological forces that operate to situate gender inequalities within a normative and functional framework, a more recent shift is also exploring the ways that education can be used to understand the "nature of gender identity and the ways that educational discourse shapes the modern individual' (Dillabough, 2001: 17). Understanding the complexity of identity 
construction at the level of the agent is important because, as this article will show, an emphasis on identities constructed around ideals associated with a 'freedom to be' could be considered as reinforcing gender inequality, albeit in different ways. This is because a discourse that promotes the notion of self-constructed biographies does not account for persisting cultural gendered norms and expectations. Against this background, this article explores perceptions of the role of education as a potential medium of transformation and as a vehicle to challenge and renegotiate symbolic and cultural notions of gender identity.

Drawing on data collected at two time points over ten years, it considers eight high aspiring students and follows up on four of these, now as young women from socially disadvantaged backgrounds who aspired to and then went on to higher education. It considers their earlier aspiration, their current occupations and how these aspirations link to their sense of a gendered self. In doing so it raises important questions about persisting cultural hegemony that promotes equality yet continues to position women as 'mother' and 'homemaker', leaving those that reject the identity feeling defiant and defensive. It will also consider how, on the one hand higher education can provide the means to renegotiate and redefine who one wants to be by developing skills such as confidence that are important for success, yet on the other, it does so at what appears to be the cost of some existential tensions.

\section{Background}

During the seventies and eighties a concern with the underachievement of and discrimination against girls was a key focus for studies of gender in education in the United Kingdom. Following the Education Reform Act of 1988 and the introduction of a National Curriculum in England and Wales, girls' improvement in GCSE examinations was rapid, resulting in girls outperforming boys in many subjects (Francis and Skelton, 2001). Despite their success in education attainment, equality in the labour market for women has not yet 
resulted. For example, in 2010 low paid women were still being paid around 10\% less than low paid men whilst high paid women were paid around $20 \%$ less than high paid men (The Poverty Site, 2015). A report by the European Commission (2012) also illustrated how provision and affordable childcare remains a significant barrier to women's employment across Europe.

Buser, Niederle and Oosterbeck, (2014) compared 15-year old boys and girls in the Netherlands in terms of their choice of one of four 'tracks' which they will follow for the remainder of their secondary school years. These tracks, differing in math/science intensity and prestige, are related to later career choices and to gender, with girls choosing math/science, less often regardless of ability. The researchers found in their study of 397 students in the Netherlands, that when the students' 'competitiveness' was judged in an experiment, , found boys were much more competitive than girls in the academic choices that they made with respect to subject chosen, even when controlling for academic ability ( However, it could be argued that competiveness is not a natural trait and may in part be explained by the fact that in contrast to males, girls face a much more uncertain and precarious position in the labour market (Biggart, 2002). Reay (1998) theorises this situation by usefully drawing on Bourdieu and pointing to the notion of a 'gendered habitus;' a set of dispositions related to experience within a gendered society and suggests that whilst girls recognise a need for educational credentials, their aspirations will reflect opportunities perceived as available to them in the labour market, alongside the gendered experience that shapes habitus. This understanding will therefore further impact the choices that some girls from different social backgrounds feel they can make.

Whilst drawing on different theoretical perspectives, Biggart (2002) and Reay's (1998) arguments in relation to competitiveness are somewhat similar to that of Beck (1992), who considers how gender can be important in determining how able to compete one is. Beck 
suggests that, although there has been liberation for women from the traditional 'female status fate' (1992:111) paradoxically their choices will still be constrained by their gender. This suggests then, that whilst the process of modernization and individualization has given women a 'freedom from' it has not provided 'freedom to'. For Beck, this can be explained by the fact that as long as children are assumed to remain an essential part of women's lives, women will always have obstacles to overcome, for example, ties to children affect their ability to compete in a competitive labour market and to achieve economic autonomy. In terms of females' future aspirations, 'values of autonomy [and] independence... are valued much more strongly than in the past. A job or career has become part of a women's life project because it promises recognition [and] money of their own' (Beck and BeckGernsheim, 2001:102). However, as the structure of the workplace does not always reward women in terms of income relative to men, and offers little support (in terms of good, affordable childcare) for combining these goals with motherhood, for Beck, choices will always be restricted. Whilst young people believe, in principle, that childcare should be the joint responsibility of both parents, they are also aware that in practice, this role is most often carried out by women (Tinklin, Croxford, Ducklin and Frame, 2005). Implicit then, is the idea that gender remains, despite some ideological shifting, very salient within the occupational and related future identities of young girls; defined as they are by a reflexive understanding of the social expectations of their gendered self-i.e. that whilst women are free to choose their future paths, gendered social expectations in relation to motherhood remain relevant.

Crucial to understanding the career and life choices an individual makes is the notion that individuals rationalise and evaluate their choices, and do so on the basis of knowledge of the labour market, a market defined by its competition and demand for skills. According to Beck (2001), to understand social inequality one must also recognise how an individual's 
reflexive understanding of their own life situation shapes their responses to these broader social changes. Education is central to the skills drive that defines the labour market and is a fundamental dimension of labour market changes and links significantly to the competition that Beck refers to. Competition requires people to advertise their 'individuality... uniqueness of their work and of their accomplishments' (2001:33); educational credentials thus become an important means by which people can do this. Whilst Beck (1992) asserts that educational accomplishment can only ever protect against downward mobility, the belief that upward mobility is possible is what leads students to construct and pursue individualised career opportunities, where 'planning one's own educational life course...[means a student]...becomes the producer of his or her own labour situation, and in this way, his or her social biography' (93). The idea that students must decide for themselves their future identities rather than follow in the footsteps of past tradition is expressed in the work of $\mathrm{Du}$ Bois-Reymond (1998). In a longitudinal study of adolescents in the Netherlands Du BoisReymond identified two types of decision making that illustrate how future aspirations are very much bound up in individual expectation of future identities and are understood as reflecting either a 'normal biography' or a ‘choice biography'.

Normal biographies refer to traditional life trajectories associated with class and gender. Typically the domain of the working class, normal biographies refer to aspirations and ambitions that are gender and class specific, for example, males in breadwinner, blue collar manual worker jobs, roles as wives and mothers for females. Choice biography, primarily associated with the middle classes, refers to an individual's ability to decide autonomously on a course of action to follow i.e. they decide for themselves what they want to be. However, options must be evaluated against each other, justified whilst, at the same time, a preferred course of action may be closed or simply unavailable to an individual. 
Research by Francis, Hutchings, Archer and Melling (2003) supports the idea that the choices girls make can be seen to be as generally much more educationally ambitious and focused than they were twenty years ago. This idea is also supported in data for 2012/13, which clearly shows that more than half the applicants accepted for higher education were females compared to 42 per cent of males (Department of Business Innovation and Skills, 2015). In addition, Francis et al. also highlight the fact that the majority of girls in their study were aspiring to professional careers, careers traditionally performed by men. This development is interesting given that marriage and motherhood were once seen as the only viable future career option for working-class girls (McRobbie, 1978). Changing patterns of women's employment as well as the integration of feminist ideas has resulted in working class girls being attracted to a new set of values (Connell, Asheden, Kessler and Dowsett, 1982) and having higher aspirations for themselves (Baker, Sammons, Blatchford; Sylva, Melhuisg and Taggart, 2014). However, whilst some academics argue that thinking about gender in class terms is not helpful because many people no longer define themselves this way, as Walkerdine (2003) notes, gendered class inequalities still remain.

Despite the fact that gender class inequality remains, many young working class women do aspire highly. Despite the fact that in 2012-2013 only 33 per cent (Source: Higher Education Statistics Agency) of male and female students in Higher Education were from backgrounds considered as working class. This figure becomes much lower when considered in relation to number of students from this background who could apply. Despite this though, the fact is that numbers are slowly rising demonstrating that some working class students, including girls, clearly do aspire to higher education and some do make it. In explaining this trend Hubbard (2005) suggests that observing under- educated mothers struggling financially, serves as a powerfully motivating factor in future aspirations in explaining this trend. The young women in her study cited the hardship experienced by their mothers as the reason their 
mothers encouraged them to 'aim high' and avoid the same fate. Research by Fuller (2009: 2014) also illustrated how ambitions for higher education of girls from socially disadvantaged, working class, backgrounds were strongly connected to a belief in their ability to succeed.

However, a report by the OECD stated that women are much less likely to make it to 'the top of the career ladder and are much more likely to end their lives in poverty' (2012:2). Amid discourse that sees the emancipation of women in relation to their social, political and civil rights, there is alongside this discourse, a strong and powerful underpinning onus on personal responsibility, where economic 'success' and "being the best you can be' is emphasised for all young people but for girls in particular (Harris, 2006). Thus, as Fuller $(2009 ; 2016)$ found, whilst a belief in meritocracy is an important driving force in aspiration and ambitions, an onus on the individual means women are constructing a biography that is constrained and limited by social structures but where the responsibility of success or failure is laid at the door of the individual and not that of society.

Developing this idea further, Existentialists hold that reality is contained in being, in experience. Thus, how we see ourselves and the meaning we apply to our lives, is shaped by our experiences. When applying these ideas to gender and existentialist feminism in particular, the relationship between individuals and groups and how these limit or constrain choices is considered as important in understanding gendered identity and experience. How gender is understood as an intrinsic part of a person's identity would therefore become strongly evident in what an individual aspires to and what they then become. De Beauvoir (1997) illustrates these ideas with her focus on the anxieties that are experienced and that emerge from the considered choices a female makes about the life she wants. What this means is that a female is free to choose the life she wants but, this freedom creates anxieties and is what exemplifies existential concerns. This paper argues that existential tensions, if 
they exist, are important to understand because they link so strongly to a person's sense of self and their understanding of the choice and autonomy they have to live the life they want.

This article draws on these ideas, to provide the theoretical basis for this study i.e. that whilst social structure may influence and shape social identity, in terms of reproducing social positions, individuals are also reflective and rational and are able to attempt to redefine and renegotiate predicted life course outcomes. Within this framework the article considers the following question: does higher education helps facilitate an individual's sense of their ability to construct their identity in relation to their gendered self-i.e. does higher enable a women to aspire to a self that moves beyond traditional understandings of mother/carer etc.? In doing so, the key concept of 'gender identity' is understood to be the social and cultural, and not biological, difference of being male or female, and how this impacts on how an individual views themselves, as well as their beliefs about how other people view them.

\section{Methods}

\section{Research design}

The research reported here adopted a longitudinal design drawing on data from eight students when they were 15 to 16 (as part of a larger two year study in 2004 - 2006 of girls' aspirations for higher education ) and then data from follow up interviews with four of these, who are now women aged $25-26$ years old. For the original study data was collected from an underperforming school on Special Measures ${ }^{1}$ where academic achievements was low and consequently, low aspirations were the expected norm. Data was collected from deviations within the case; that is students with high aspirations. Data collection was via an ethnography using qualitative methods, outlined later, and focused on experiences of school, relationships

\footnotetext{
${ }^{1}$ Special Measures - 'Schools are made subject to special measures under section 44(1) of the Education Act 2005, where the Chief Inspector is of the opinion that: '....the school is failing to give its pupils an acceptable standard of education, and the persons responsible for leading, managing or governing the school are not demonstrating the capacity to secure the necessary improvement in the school.' Education Act 2005, s44(1) http://www.legislation.gov.uk/ukpga/2005/18/contents.
} 
with family, peers and teaching staff as well as ambitions for the future. The 10 year longitudinal dimension to this research offers a particular strength, exploring perspectives of students at the ages of 15-16 and again at 25-26 years of age.

\section{The context}

The school which formed the original case study for the research was a state secondary school located in an economically thriving town in the south east of England but was in, and remains in, the top ten per cent of areas most deprived nationally for education, skills and training and crime as well as in the top 10 per cent of areas for income deprivation affecting children, according to the English Indices of Deprivation (2004). The school struggled with consistently low academic achievement rates (some 20 per cent lower than the national average for GCSEs at the time of the study) and was placed on Special Measures at the time the original field work began. More than 50 per cent of the school population were from ethnic minority backgrounds, with students drawn from the locale as well as attending as a result of parental preference for single sex schooling. The women included in this research were students at the school and also lived in the neighbourhood in which the school was situated.

\section{Data collection}

In the original study, data was collected from students who were in year ten and year twelve (the penultimate year of compulsory schooling and the first year of post-compulsory study respectively) and they were followed for a period of two years, up until several months after the results of their GCSEs and A levels, examinations taken at age 16 and 18 in England. The research relied upon a variety of data collection methods that included: participant observation, focus groups, structured and semi-structured interviews. In the follow 
up study, data was collected through two interviews with four of the original eight, carried out either face-to-face or over the phone. Whilst a telephone interview was not ideal in terms of developing rapport, as two of the participants were no longer local, it was convenient. However, it did have an impact on the data collected and is reflected in the fact that data is not as extensive for two of the interviews. The first interviews lasted a maximum of one hour, the second, between 20 and 30 minutes. In the interviews, participants were asked to reflect back on their younger self as well as consider where they were now. A narrative, life history approach was initially adopted, an approach that enabled participants to flag up and highlight the stories that they considered important in discussing the events of their lives since completing their schooling. Interviews then moved to a more semi-structured approach to consider questions related to higher education experiences, future plans and career ambitions.

\section{Sample}

A convenience sampling approach was adopted in the original sample i.e. a sample drawn from those who were willing to participate amongst those to whom I had access (Cohen, Manion and Morrison, 2001). From the overall sample of 63, eight girls had high aspirations, that is, ambitions for a university education, with four of these involved in the follow-up study. All came from manual or unemployed households, as defined by parental occupation, and had parents who had not completed a higher education. In this article I focus on four of these students and then as women. In this study parents' occupation were as cleaners, taxi driver or unemployed. As students, the participants had mixed levels of attainment levels; as women, the four follow-up participants had all completed an undergraduate degree, with three in full time employment and one a full time mother. One young woman was of mixed Caribbean ethnicity, one Black African, one White and one Pakistani - although all were born in the United Kingdom, However, whilst ethnicity is 
extremely relevant in understanding educational outcomes, the experience of ethnicity is still underpinned by social economic status and, given the small sample size, was not a focus of analysis. The selection of these four participants was again based on convenience: one of the four had maintained some contact with me since the original research and after agreeing to take part in a follow up interview, contacted the other three on my behalf through Facebook.

\section{Data analysis}

Transcripts from interviews were analysed to identify key themes of higher education, acquired through a process of iteration. Although software is available to support this process, colour coding was used instead. This inductive and systematic approach allowed for an exploration of the data which permitted the themes that appeared relevant and significant to notions of gender to begin to emerge and be categorised. A thematic analysis, in relation to the topics and themes that arose in the interviews, was carried out in relation to the discourse evident in relation to content and meaning and then later, power and inequality. Categorising the data in this way allowed long narrative to be condensed. However, frequency of 'content' was not an aspect of this research - given the small sample size. Instead, the analysis focused on the discourse and narrative of the women - not in terms of a chronological story but from a discursive and dialectical stance, that Kvale and Brinkman (2009) suggest enables the exploration of the contradictory. This approach to the analysis resulted in additional follow up interviews to explore the area of gender in more depth and using a much more deductive approach. To compare for similarity and difference between time one and two, transcripts were explored and considered in relationship to previous interviews and indicated a high degree of thematic similarity in the categorisation of key areas, in that ideas related to the value of higher education and motherhood, for example, remained very similar. Both the first interviews and follow up interviews that explored emerging themes permitted the 
establishment of credibility and confidence in the data analysis, in addition, participants were asked to verify that the key themes identified in the first follow up interview were valid ones. Lincoln and Guba (1985) consider this approach an important process in establishing the trustworthiness of qualitative data analysis. Themes related to higher education and gender identity form the focus of this article.

All University ethical guidelines were complied with in carrying out this research. In particular, all those taking part gave informed consent and were assured of anonymity. Quotes that follow in the results section use pseudonyms.

\section{Findings}

This article considers whether higher education helps facilitate an individual's ability to reconstruct their identity in relation to their gendered self. This question is firstly addressed by considering gender in relation to the future aspirations of the young women when aged 15 in the original study; there is then an exploration of whether higher education empowered the four participants now women of 25 and 26 years old in relation to their expectations for themselves.

Gender for the high aspirers when at school appeared as a significant construct in the student's sense of self and future identities. Implicit in students' comments was the idea that self-reliance and financial independence were a desirable pre-requisite before marriage and children. A desire to re-negotiate typical gendered stereotypes, for example, as that of dependent within marriage, rather than conform to them was very apparent and education and particularly higher education was seen as the route to occupational choice and economic security. Economic security was synonymous with independence and self-sufficiency and these were important goals when high aspiring students contemplated possible future 
relationships. Being able to support themselves as non-dependents in any potential relationship was fundamentally important. Economic self-reliance is an important prerequisite before marriage and children is, as Beck and Beck-Gernsheim (2002) state, one of the resulting consequences of modernity and 'rhetoric of equality' (2002:102) is that women increasingly recognise the need to be able to provide for themselves. However, whilst marriage and families were important for some, both were seen as having less status than having a career. All of the high aspirers saw their gender as constraining but paradoxically believed that equality of opportunity existed, alongside freedom to pursue any occupation of choice. Rather alarmingly, this comment suggest that this type of inequality was accepted and was seen as simply 'the way things are'

\section{Higher education as investment}

Now as young adult women, two of the four from the original study, took time out before going on to higher education, wanting to 'make sure' that it was the path they needed to take with respect to career opportunities:

I took a year out first as I wanted to make sure that I wanted to go to university...I didn't want to just go and hope for the best...I wanted to make sure that I had that want of learning because otherwise it's a waste of money, £25,000 is not cheap.....so I went and worked for a year...but I wasn't really enjoying it... and I could see myself not earning as much as I possibly could if I went into a different career path (Deborah, 26)

On reflecting back on the choices that they made, all were $100 \%$ sure that they would not be in the careers they had or have the skills they had acquired, without the 'investment' in a university degree: 
I wasn't really sure what I wanted to be, I quit college and got a job just as like office admin... when I was there I discovered what a quantity surveyor was and they trained me up...I was struggling without a degree to progress any further...so I went to University, straight in to the second year...I got a job a year after graduation and the degree meant I wasn't on a trainee's wage but a fully qualified one, because of my experience...(Emily, 25)

Having confidence, determination and skills in communication were all seen as the advantages of their higher education, as Fatima (25) says "the experience helped me become more confident... and independent...I am kind of on my own now [because of family difficulties] but the experience has taught me I can motivate myself to do well and be where I want to be in life...I feel I am a driven person, I always have been but [university] has helped me know what I want in life [and have the confidence] to work towards it". This was also true for Deborah:

I got to consider things I wouldn't normally think about ... you could speak freely, with no judgement...I left that degree [and now challenge] everything...you can ask my manager (laughs). The skills I learnt have helped me analyse and has given me a confidence in myself, a belief in myself actually... I spoke to some [I would not have spoken to before] because I used to, you know, easily think that I was inferior to someone like that.

The idea of knowledge promoting confidence in the workplace was also highlighted by Emily, who entered university straight into year 2 because of her prior professional experience. Emily found the content knowledge provided by her degree was important in relation to her sense of credibility and as a means of validating her place in a male dominated workplace "if you have an accreditation to back you up then it sort of, it gives you a step up, but it is hard... [and I am] confident in my ability now, after the experience "For Sabrina however, university was important for promoting her sense of independence, living at home, 
travelling to London to study on a daily basis promoted skills of self-reliance despite not enjoying the journeying.. As the first in her family to go to university, her sense of achievement and pride is important to her and has had a bearing on her ambitions for her own daughters as well as her confidence to raise them well. Initially undecided whether she should go or not, Sabrina states that she was very glad she did go and believes it has been important to her self-confidence "it was a very different experience to school and has been important to my understanding about the way the world works (laughs)".

For three of the participants 'security' was a very strong theme throughout the interviews and related very closely to the economic independence that they had spoken of when they were younger. Salary and a desire for economic control was particularly strong for Deborah, now married. She attributed the need for financial control to her childhood experiences:

Going to uni was largely a financial decision, and security more than anything...I have always wanted to be the breadwinner, I have always wanted that role...I think it's the sense of control. I don't ever want to feel that someone's looking after me...I don't ever want to feel trapped. I am a bit of a pessimist and if something weren't to work out between me and my husband, I don't want to be financially stuck...I am in control of the finances anyway, he puts his pay cheque into my account at the end of every month...my parents, they're terrible with money and I know my mum is not happy where she is but she's financially trapped there and has been for years.

In terms of their identity, for Fatima having a university degree conferred a sense of status "people get impressed when they see it on your CV, they're like, "oh wow, okay”, they see it as a good thing”

\section{Higher education and gender identity}


Emily, having supported herself through university was strongly driven to achieve and hoped to be able to move for work to the Middle East in the next two years, a place where she believed she could make a lot of money. For Emily, having a degree had "opened a lot more doors", particularly in a career she saw as very male dominated and where being a woman has many disadvantages:
My area of work is massively male dominated, about $90 \%$ are male so the minute you walk into a room you are at a disadvantage... if you have an accreditation to back you up it sort if gives you a step up, but it's hard...sometimes I walk into a room and if I'm talking to really old fashioned guys they're really not interested and some of them won't even talk to me...I try to win them over, by convincing them that I do know what I am talking about...I am not sure if they think I am stupid but it would be completely different if I was a male 25 year old walking into that room...I am confident in my ability now, after going to Uni, so I just refuse to act differently.

Emily was very tentative in talking about children, seeing them as something that were a very long way in the future and only after she had had the chance to first live life to the full and “experience everything I possibly can". Implicit in Emily's comments was the idea that having children sounded the death knell for your career because having children would "change your life and career massively...I am not sure how people would respond to that in any case". Conversely, Sabrina (26) appeared almost embarrassed about giving up work after her degree to be a full-time mother to her two daughters, "I will get a job, just not now, my job is to look after my daughter's, and you know, that's just as important...I will get one though, when they are older". Her belief in the value of her decision to be with her daughters was stated with a sense of defiance and an implicit sense that she would be judged.

For Deborah, already on her second promotion, being a female was not considered as being a barrier to having a career as well as a family. Whilst she claimed she never discussed 
her family plans at job interviews, believing it would bias an interview panel against her, having a child was something very important to her:

My degree was for security, it was investing in myself for my future...I want to have security for my children, I want to be able to give them things...me and my husband didn't really have that, we didn't feel as secure as we could've when we were younger...it's harder for women to forge their own security than it is for men [so when it comes to children] my husband will be the care giver and I will be the breadwinner, because we invested in me and my future and my education and I think that was down to me...I am not saying I won't care but I want a career for myself as well, I want the satisfaction...it is vital to who I am...

For Deborah, a higher education had offered her a 'freedom from' insecurity and anxiety as well as an opportunity for a 'freedom to be'. Despite discussing her future family plans assertively, she also spoke with a tone of challenge; justifying and rationalising the choices she and her husband had made, stating that it was only ideology that says it should be otherwise. Despite asserting her right to create a biography of her own choosing, that she might do so was positioned as something that would be perceived dismissively and negatively, and more so because she was a woman:

It's historical, ideological isn't it, that the woman stays...I mean, it's archaic now, because women traditionally stayed at home, made dinner, looked after the children ...it's just an ideology that is dying out but it's still quite prevalent... and you can't actually outwardly call yourself a feminist...or people think "oh no, here she goes again, talking about women's rights"...of course, they would only be saying that because I am a bloody woman!

Despite some implicit contradictions and tensions around their female identity, for all older women included in this research, a higher education had been as empowering as their 
younger selves had imagined as Deborah put it: "knowledge is power and because of my degree I feel empowered"

\section{Discussion and conclusion}

The data presented in this article provides a small snapshot in time and in no way claims generalisability. However, it does raise interesting considerations in relation to the importance of higher education in enabling the women in this study to construct their own identity in relation to their gendered self. Gender was important to the women when they were at school and remained important as young women, albeit in different ways. When they were students they appeared to desire a re-negotiated future role which was one of nondependent within a relationship; a desire for equality and economic independence remained true for three of the four as older women as is clear in the comments of Deborah, Emily and Fatima. Aspirations for high status and high salaried occupations (which are very much associated with economic independence and greater choice) were then, and still were ten years later, explicitly demonstrated when students discussed their desire for self-reliance i.e. being able to provide for themselves. Marriage and children were also much more loosely linked to the future life plans of the three who were not yet mothers, whilst Sabrina discussed defensively her role as mother, suggesting that this choice might be seen to imply a lower status to the aspirations she had as a student. In renegotiating traditional gendered identities in future trajectories, the participants continued to see gender as a very powerful variable across the ten year time span, specifically in relation to the desire of two of the participants to very explicitly challenge normative practices of gender roles and childcare in particular as expressed by Deborah and Emily.

Gender clearly matters as implicit theme within student self-identification and ideas associated with gendered identities are explicitly expressed by Beck's view that women 
recognise the need for self-reliance may be useful in explaining the women in the present study. Beck (1992) stated that feminism has been useful in emancipating women yet, as bearers of children, they will always be constrained in what they can actually achieve. This constraint is because children pose a significant hurdle for women to overcome, in terms of their ability to compete in the labour market just as Beck (1992) and Beck and BeckGernstein (2001) suggest. Both Deborah (who chose to challenge the role of primary caregiver) and Emily (for whom children featured only very loosely in her future plans) appeared to experience some existential tension in connection to the 'choice-biography' (DuBois Raymond, 1998) they aimed to create, i.e. that of career women. This tension was evident in the ways they acknowledge, but do not directly attribute to their own sense of self, the clearly gendered discrimination that they witness and experience and the ways they work to challenge these. In some sense, whilst they acknowledge gender inequality, this inequality is positioned as external to them; an experience without influence which is suggestive of the normative ways that such inequalities are experienced subconsciously within the gendered habitus that Reay (1998) suggests.

Whilst not articulated in these terms, the young women's earlier aspirations as students for enjoyable, well paid employment, employment that they believed permitted greater freedom and independence but more importantly, security, was still true as women and remained very important for three of the four. Their own earlier experiences were an important underpinning factor in explaining how this desire linked to the gendered identities that they were creating, where good salaries and promotion were important markers to the sense of self of both Deborah and Emily.

For the participants in this research, higher education had allowed these girls from working class backgrounds to find a confidence, independence and a sense of security that was not possible, from their perspective, without graduate employment. Whether this would 
have been true or not, for those included in this paper, higher education had indeed enabled them to challenge and renegotiate the classed identity and the background they grew up in if they wanted to. As Francis et al. (2003) note, girls are much more ambitious now than they were twenty years ago. However, as they attempt to self-define in relation to who they want to, either as a mother or career women in the new neo-liberal landscape of career choice that Walkerdine (2003) discussed, an emphasis on subjectively constructed biographies can ignore tensions that appear as the result of persisting structural inequalities. Thus, whilst an existential self is very evident in the comments of the women and their younger selves, the ,the 'self' for these young women was still defined by the structures that the self is positioned in, structures that shape gendered norms and expectations, as De Beauvoir (1997) also makes clear.

This article sought to explore the role of higher education in challenging and renegotiating the gendered identity of the women included and suggests that it does indeed facilitate a sense of emancipation whilst paradoxically, at the same time reinforcing gender inequality. Whilst the findings are very much context specific and may not be true elsewhere, it highlights an implicit angst connected to the identities the women are constructing, positioned as they are within an ideological political and economic landscape that still promotes a subversive cultural hegemony; one that suggests 'freedom to be' via education without offering 'freedom from' gendered norms and expectations. In doing so it also raises important questions about the dialectic position of education in relation to promoting greater equality; where educationally women have greater attainment and access than ever before but still appear to face challenge when attempting to seek parity in the selves they strive to be.

\section{Acknowledgements:}


The author is grateful for the feedback received on this paper, feedback that has made the paper much stronger than it was.

\section{References:}

Baker, W., Sammons, P., Blatchford, I-S., Sylva, K., Melhuish, E. and Taggart, B. (2014). Aspirations, education and inequality in England: insights from the Effective Provision of Pre-school, Primary and Secondary Education Project. Oxford Review of Education. Vol. 40, No. 5, pp 525-542.

Beck, U. and Beck-Gernsheim, E. (2001). Individualization. London, Thousand Oaks, New Delhi, Sage Publications.

Beck, U. (1992). Risk Society: Towards a New Modernity. London, Thousand Oaks, New Delhi, Sage Publications.

Biggart, A. (2002). Attainment, Gender and Minimum-aged School Leavers' Early Routes in the Labour Market. Journal of Education and Work. Vol. 15, No. 2, pp. 145 - 162.

Buser, T., Niederle, M. and Oosterbeck, H. (2014). Gender, Competitiveness and Career Choice. The Quarterly Journal of Economics, Vol. 129, No. 3, pp. 1409-1447.

Connell, R.W., Ashenden, D.J.; Kessler, S. and Dowsett, G.W. (1982). Making the Difference: Schools, Families and Social Division. George Allen and Unwin.

Cohen, L.,Manion, L. and Morrison, K. (2001). Research Methods in Education, Fifth Edition. Routledge Falmer.

Department of Business Innovation and Skills. (2015), Statistical First Release: Participation Rates in Higher Education, Academic Years 2006/2007 - 2013/201, (https://www.gov.uk/government/uploads/system/uploads/attachment_data/file/458034/ HEIPR_PUBLICATION_2013-14.pdf - accessed 2015) 
Dillabough, Jo-Anne, Gender Theory and Research in Education: Modernist Traditions and Emerging Contemporary Themes in Francis, B. and Skelton, B. (Editors) (2001). Investigating Gender: Contemporary Perspectives in Education. Open University Press.

De Beauvoir, S., (1997), The Second Sex, The Vintage Classics.

Du Bois-Reymond, M. (1998). 'I Don't Want to Commit Myself Yet': Young People's Life Concepts. Journal of Youth Studies. Vol. 1, No. 1, pp. 63 - 79.

European Commission. (2012). Female Labour Market Participation ,.Europa.

Francis, B. and Skelton, C. (2001). Investigating Gender: Contemporary Perspectives in Education. Milton Keynes; Open University Press.

Francis, B., Hutchings, M Archer, L and Melling, L. (2003). Subject Choice and Occupational Aspirations among Pupils at Girls' Schools. Pedagogy, Culture, Society. Vol. 11, No. 3, pp. $425-442$.

Fuller, C. L. 2009. Sociology, Gender and Educational Aspirations: Girls and their Ambitions. Continuum, New York. pp201

Fuller, C. 2014. Social capital and the role of trust in aspirations for higher education. “Educational Review”, 66 (2). pp. 131-147

Fuller, C., Powell, D. and Fox, S. (2016) Making gains: the impact of outdoor residential experiences on students' examination grades and self-efficacy. Educational Review.

Harris, A. Citizenship and the Self-Made Girl in Arnot, M., and Mac an Ghaill, M. Editors. (2006). The RoutledgeFalmer Reader in Gender and Education. Abingdon and New York, Routledge.

Higher Education Statistics Agency. https://www.hesa.ac.uk/stats (accessed 2015).

Hubbard, L. (2005). The role of gender in academic achievement. International Journal of Qualitative Studies in Education. Vol. 18, No. 5, Sept. - Oct., pp. 605-623. 
Johnson, E., (1967). Existentialism, Self-Theory and the Existential Self. The Personnel and Guidance Journal. Vol. 46, Issue 1, pp 53-58.

Kvale, S. and Brinkmann, B, (2009), Interviews: Learning the Craft of Qualitative Research Interviewing, Los Angeles, Sage

Lincoln, Y.S. and Guba, E.G. (1985). Naturalistic Inquiry. Newbury Park, CA: Sage Publications.

McRobbie (1978). in Women Take Issue: Aspects of Women's Subordination. Women's Study Group. London: Hutchinson.

OECD. (2012). Gender Equality in in Education, Employment and Entrepreneurship. Repot to $\mathrm{MCN}$

Ofsted (2006). Special Measures: Monitoring Inspection of ******** School, Dec. pp1 -5.

Reay, D. (1998). 'Always Knowing ' and 'Never Being Sure': Familial and Institutional Habituses and Higher Education Choice. Journal of Education Policy. Vol. 13, No. 4, pp. 519-529.

Tinklin, T., Croxford, L., Ducklin, A. and Frame, B. (2005). Gender and Attitudes to Work and Family Roles: The Views of Young People at the Millennium. Gender and Education. Vol. 17, No. 2, (May), pp. 129-142.

The Poverty Site. http://www.poverty.org.uk/56/index.shtml (accessed 2015)

Walkerdine, V.,(2003). Reclassifying Upward Mobility: femininity and the neo-liberal subject. Gender and Education. Vol. 15, No 3., pp. $238-2$ 
